\title{
KEMAMPUAN MENULIS TEKS PROSEDUR OLEH PESERTA DIDIK KELAS VII SMP MUHAMMADIYAH 1 BANJARMASIN TAHUN AJARAN 2018-2019
}

\section{THE ABILITY TO WRITE PROCEDURE TEXTS BY CLASS VII STUDENTS OF MUHAMMADIYAH 1 MIDDLE SCHOOL 1 BANJARMASIN SCHOOL YEAR 2018-2019}

\author{
Yunita Rakhmi; Zulkifli; Dewi Alfianti \\ Program Studi Pendidikan Bahasa Indonesia \\ FKIP Universitas Lambung Mangkurat \\ yunitarahmi368@gmail.com
}

\begin{abstract}
Abstrak
Penelitian ini bertujuan untuk mendeskripsikan proses pembelajaran dan mendeskripsikan hasil kemampuan menulis teks prosedur peserta didik kelas VII SMP Muhammadiyah 1 Banjarmasin. Jenis penelitian ini menggunakan dekriptif kuantitatif. Dalam proses pembelajaran guru tidak sepenuhnya berpedoman pada RPP. Hasil penelitian menunjukkan peserta didik memperoleh nilai rata-rata 73,75 (56\%) dalam menulis teks prosedur. Peserta didik yang belum mencapai ketuntasan 11 orang (44\%), sedangkan peserta didik yang telah mencapai ketuntasan 14 orang $(56 \%)$ dari seluruh sampel yang berjumlah 25 peserta didik. Maka kemampuan menulis peserta didik kelas VII SMP Muhammadiyah 1 Banjarmasin tidak tuntas secara penilaian klasikal.
\end{abstract}

Kata kunci: kemampuan menulis, teks prosedur

\section{Abstract}

This study aims to describe the results of the ability to write procedure texts for grade VII students of Muhammadiyah Middle School 1 Banjarmasin. This type of research uses quantitative descriptive. In the learning process the theacher is not fully guided by the learning implementation plan. The results showed that students obtained an avarage value of 73,75 (56\%) in writing procedure texts. Students who have not reached the completeness criteria of at least 11 people (44\%), while students who have achived the completeness criteria of at least 14 people (56\%) of all samples who are 25 students. So the writing ability of Grade VII Students of Muhammadiyah 1 Banjarmasin did not lead to classical judgment.

Keywords: writing skills, procedure text

\section{Pendahuluan}

Menulis merupakan suatu kegiatan komunikasi berupa penyampaian pesan (informasi) secara tertulis kepada pihak lain dengan menggunakan bahasa tulis sebagai alat atau medianya. (Dalman, 2016 :3). Sehubung dengan pendapat Dalman diatas menulis juga dapat dikatakan sebagai proses untuk mengungkapkan, mengekspresikan gagasan, pendapat, dan idenya ke dalam bentuk bahasa tulis. Bahasa tulis dsapat digunakan untuk menceritakan, memberitahu, meyakinkan atau menggambarkan, misalnya dapat dituangkan dalam berbagai teks seperti teks narasi, teks 
argumentasi, teks deskripsi dan teks prosedur. Dalam hal ini peneliti akan meneliti kemampuan menulis teks prosedur sebagai acuan penelitian.

Teks prosedur perlu dikuasai karena dalam pembelajaran, teks prosedur merupakan teks yang menjelaskan tentang langkah atau cara melakukan sesuatu dengan lengkap, jelas dan terperinci. seperti contoh sederhana cara membuat KTP (Kartu Tanda Penduduk), cara menggunakan ATM. Teks prosedur juga bermanfaat bagi peserta didik di era modern seperti ini mereka bisa memanfaatkan langkah-langah melakukan sesuatu dengan cara yang unik dengan membuat berbagai macam video tutorial dan mengunggahnya di media sosial sehingga dapat membuat peserta didik lebih kreatif.

\section{Berdasarkan observasi yang di-} lakukan oleh peneliti di SMP Muhammadiyah 1 Banjarmasin, terungkap bahwa penelitian mengenai teks prosedur belum pernah dilakukan di sekolah tersebut. Oleh karena itu, Penelitian mengenai menulis teks prosedur sangat penting untuk diteleti sebagaimana masih kurangnya penelitian mengenai menulis teks prosedur. Penelitian ini dilakukan sebab dalam pembelajaran bahasa Indonesia dalam aspek menulis peserta didik masih terkendala dan kesulitan dalam menulis.
Menurut pengamatan penulis, salah satu penyebabnya adalah peserta didik masih kesulitan mengembangkan bahasa lebih menarik, kesulitannya dalam pemilihan kata yang tepat dan kurangnya pengetahuan kosa-kata dalam menulis. Oleh karena itu, peserta didik harus terus dilatih dalam menulis berbagai teks salah satunya dalam hal ini adalah teks prosedur.

\section{Metode Penelitian}

\section{Jenis Penelitian}

Jenis penelitian menggunakan pendekatan deskripftif-kuantitatif. Penelitian kuantitatif dimaksudkan karena data diperoleh berupa angka-angka. angka yang dimaksud berupa skor yang nantinya akan memberikan gambaran mampu tidaknya menulis teks prosedur.

\section{Waktu dan Tempat Penelitian}

Penelitian dilakasanan di kelas VII SMP Muhammadiyah 1 Banjarmasin. waktu penelitian dilaksanakan pada tanggal 29 November 2018.

\section{Target atau Subjek Penelitian}

Target penelitian seluruh peserta didik kelas VII yang berjumlah 25 orang. Di SMP Muhammadiyah hanya ada 1 ruangan kelas VII jadi peneliti disini menggunakan teknik total sampling dengan mengabil seluruh jumlah populasi untuk dijadikan subjek penelitian. 


\section{Prosedur}

Prosedur dilakukan dengan langsung mengambil data. Pengambilan data dilakukan di kelas VII dengan memberikan tes menulis prosedur dengan tema dan pemilhan topik yang bebas.

\section{Data, Instrumen dan Teknik Pengumpulan Data}

Data dalam penelitian ini menggunakan data primer. Data primer berupa RPP dan hasil tulisan dari tes menulis peserta didik. Data tersebut adalah berupa RPP yang akan peneliti deskripsikan sesuai proses guru selama pembelajaran. Sedangkan data hasil tes menulis berupa hasil lembar kerja peserta didik yang akan dianalisis sesuai penilaian.

Instrumen yang digunakan dalam penelitian adalah tes tertulis. Tes tertulis dilakukan dengan menugasi peserta didik membuat teks prosedur yang bertujuan untuk mengukur kemampuan peserta didik dalam menulis teks prosedur.

Teknik Pengumpulan data menggunakan teknik observasi, dokumentasi dan tes. Observasi dalam penelitian ini adalah observasi partisipasi pasif artinya peneliti disini hanya sebagai pengamat dan menggunakan catatan lapangan saat proses belajar berlangsung dan hasil kerja peserta didiklah yang akan peneliti analisis. Dokumentasi berupa foto lembar kerja peserta didik serta foto saat proses pembelajaran berlangsung. Tes yang di-gunakan tes essai dengan menugasi peserta didik untuk menulis teks prosedur.

\section{Teknik Analisis Data}

Teknik analisis data dalam penelitian ini dilakukan dengan beberapa cara yaitu:

1. Data dari hasil observasi di analisis untuk mengetahui bagaimana saat proses pembelajaran dan hasil menulis teks prosedur.

2. Data yang terkumpul berupa hasil tulisan peserta didik dianalisis dengan menggunakan teknik analisis deskriptif. Untuk menganalisis data dilakukan langkah-langkah berikut:

\subsection{Membuat Daftar Skor Mentah}

Setelah melakukan tes, selanjutnya adalah memeriksa hasil kerja peserta didik. Penentuan aspek yang dinilai dalam menulis teks prosedur peserta didik berdasarkan penilaian yang telah ditetapkan.

\section{Tabel. Klasifikasi Penilaian Teks}

\section{Prosedur}

\begin{tabular}{|c|c|c|}
\hline No & $\begin{array}{c}\text { Aspek Yang } \\
\text { Dinilai }\end{array}$ & Skor \\
\hline 1 & Isi & 4 \\
\hline 2 & Struktur Teks & 4 \\
\hline 3 & Kaidah Penulisan & 4 \\
\hline 4 & Ciri Kebahasaan & 4 \\
\hline \multicolumn{2}{|c|}{ Jumlah skor } & 16 \\
\hline
\end{tabular}


1.2 Menghitung Nilai Kemampuan Peserta Didik

Dalam kurikulum 2013 setiap penilaian menggunakan skala 100. (Permendikbud No. 104).

Nilai $=\frac{\text { skor pemerolehan }}{\text { sḱor maḱsimai }} x$ skor ideal

1.3 Mencari rata-rata menggunakan rumus, $\mathrm{TBX}=\frac{N}{S N} \mathrm{X} 100 \%$

Berdasarkan penilai kurikulum 2013, ketentuan belajar siswa dapat dilihat berdasarkan tabel berikut:

\begin{tabular}{|c|c|c|c|}
\hline No & Predikat & Nilai & Kategori \\
\hline 1 & A & $90-$ & Sangat \\
& & 100 & Mampu \\
\hline 2 & B & $80-$ & Mampu \\
& & 89 & \\
\hline
\end{tabular}

\section{Hasil dan Pembahasan}

\section{Proses Kegiatan Pembelajaran}

Menulis Teks Prosedur

Hasil menulis dari peserta didiklah yang dijadikan data dalam penelitian ini. Dengan menggunakan metode deskriptif. Peneliti mendeskripsikan Rencana Pelaksanaan Pembelajaran (RPP). Dari yang peneliti amati ada beberapa hal yang ada didalam RPP, guru tidak melakukannya saat proses belajar mengajar berlangsung. Dari segi materi yang dicantumkan dalam RPP yaitu materi pembelajaran reguler, guru sudah menjelaskan secara rinci langkah-langkah menulis teks prosedur berdasarkan dengan struktur yaitu berupa

\begin{tabular}{|c|c|c|c|}
\hline 3 & C & $\begin{array}{c}70- \\
79\end{array}$ & $\begin{array}{c}\text { Kurang } \\
\text { Mampu }\end{array}$ \\
\hline 4 & D & $<70$ & Tidak \\
& & & Mampu \\
\hline
\end{tabular}

\section{Klasifikasi Ketuntasan}

Pada pembelajaran ini terdapat dua kategori penilaian yaitu tuntas dari segi ketuntasan belajar (KBM) dan ketuntasan secara klasikal. Dalam pembelajaran Bahasa Indonesia SMP Muhammadiyah 1 Banjarmasin, Ketuntasan Belajar Minimal $(\mathrm{KBM})$ adalah 70. Selain nilai individu yang harus dicapai, ketuntasan secara klasikal juga harus dipenuhi minimal (70\%) jika kurang dari (70\%) maka kelas tersebut tidak tuntas secara klasikal.

tujuan, bahan dan alat. Sedangkan pada materi yang membahas ciri kebahasaan guru hanya mengulang kembali, karena pem-belajaran ciri kebahasaan sudah pernah diajarkan pada pertemuan ketiga sedangkan pembahasan mengenai kaidah penulisan guru hanya memberikan penjelasan yang tidak begitu dalam. Guru hanya menjelaskan seperti judul dalam menulis teks prosedur ditulis dengan huruf awal menggunakan huruf besar, penggunaan kata ulang ditulis dengan menggunakan tanda (-).

Di dalam RPP guru juga mencantumkan media yang digunakan 
adalah laptop, lcd proyektor dan Caption.

Namun saat peneliti mengamati proses pembelajaran dari awal hingga akhir pembelajaran guru sama sekali tidak menggunakan laptop dan lcd proyektor sebagai media dalam pembelajaran. Guru hanya menggunakan gambar (cap-tion) sebagai media pembelajaran dan hanya diberikan pada waktu kegiatan evaluasi. Gambar dibagikan guru kepada masing-masing kelompok berbeda-berbeda.

Pada kegiatan inti yaitu mengamati, menanya dan mengasosiasi sudah sesuai dengan RPP.Guru mengajak peserta didik membaca materi bahan yang akan dipelajari guru juga mendemonstrasikan bagaiman "Cara Mencuci Tangan dengan Benar" sesuai topik yang ada dalam RPP. Namun pada kegiatan mengomunikasikan didalam RPP tercantum peserta didik mampu memeragakan hasil yang ditulis secara lisan. Saat proses pembelajaran hendak berakhir peneliti melihat kegiatan mengomunikasikan tidak terlaksanakan. Setelah tugas yang diberikan selesai peserta didik tidak memeragakan hasil yang ditulis sesuai dengan yang dicantumkan di dalam RPP. Selanjutnya dalam kegiatan akhir gurulah yang memberikan kesimpulan tanpa adanya umpan balik dari peserta didik.

\section{Hasil Perolehan Analisis}

Dalam tahap ini di deskripsikan hasil peneilitian tentang kemampuan menulis teks prosedur. Hasil penelitian yaitu uraian yang menggambarkan tingakat kemampuan menulis teks prosedur dengan dinilai berdasarkan aspek isi, stutruktur, kebahasaan dan penulisan yang berupa hasil kuantitatif. Untuk lebih jelasnya data yang diperoleh dari hasil penelitian yang dilaksanakan di SMP Muhammadiyah 1 Banjarmasin sebagai berikut:

\section{a. Skor Mentah}

Skor mentah hasil tes menulis teks prosedur peserta didik dapat dilihan pada tabel berikut.

Tabel 1: Skor Mentah

\begin{tabular}{|c|l|c|c|}
\hline No & \multicolumn{1}{|c|}{ Nama } & Skor & $\begin{array}{c}\text { Rata- } \\
\text { Rata }\end{array}$ \\
\hline 1 & Ahmad Haikel & 13 & 13 \\
\hline 2 & $\begin{array}{l}\text { Akhmad } \\
\text { Ridhoni }\end{array}$ & 13 & 13 \\
\hline 3 & Aliya & 13 & 13 \\
\hline 4 & $\begin{array}{l}\text { Andini } \\
\text { Istiqomah }\end{array}$ & 15 & 15 \\
\hline 5 & Andre & 9 & 9 \\
\hline 6 & Anisa Hafifah & 11 & 11 \\
\hline 7 & Arief Rizani & 13 & 13 \\
\hline 8 & Karina Aprile & 15 & 15 \\
\hline 9 & $\begin{array}{l}\text { Lisa Ardita } \\
\text { Nurlela }\end{array}$ & 11 & 11 \\
\hline 10 & $\begin{array}{l}\text { M. Abi Nubli } \\
\text { Rosyadi }\end{array}$ & 13 & 13 \\
\hline 11 & M. Taufik & 10 & 10 \\
\hline 12 & $\begin{array}{l}\text { Muhammad } \\
\text { Ridho }\end{array}$ & 13 & 13 \\
\hline 13 & $\begin{array}{l}\text { Muhammad } \\
\text { Ade Saputra }\end{array}$ & 9 & 9 \\
\hline 14 & $\begin{array}{l}\text { Nadya Elmira } \\
\text { Amalia }\end{array}$ & 10 & 10 \\
\hline 15 & Najib Khairani & 12 & 12 \\
\hline 16 & Naswa Hanifah & 11 & 11 \\
\hline 17 & Noor Amin & 10 & 10 \\
\hline & \multicolumn{2}{|l|}{} \\
\hline
\end{tabular}




\begin{tabular}{|c|l|c|c|}
\hline 18 & $\begin{array}{l}\text { Rafli Achmad } \\
\text { Samudera }\end{array}$ & 10 & 10 \\
\hline 19 & Ricko Samudra & 13 & 13 \\
\hline 20 & Rina Aulia & 12 & 12 \\
\hline 21 & Sovina Assifa & 10 & 10 \\
\hline 22 & $\begin{array}{l}\text { Tria Azis } \\
\text { Tsunamianto } \\
\text { Purno }\end{array}$ & 14 & 14 \\
\hline 23 & Utiya Rahmi & 12 & 12 \\
\hline
\end{tabular}

\section{b. Kemampuan Menulis Teks Prosedur}

Kemampuan menulis peserta didik dapat dilihat melalui penguasan topik serta tema yang dipilih. Dengan memperhatikan strukutur, isi, kaidah penulisan, dan ciri kebahasaan. Kemampuan menulis teks prosedur dapat dilihat pada tabel di bawah ini. Data dari skor mentah dianalisis sesuai dengan prosedur dengan rumus.

Nilai $=\frac{\text { Skor Perolehan }}{\text { Skor Maksimal }} \times$ skor ideal

Tabel 2. Distribusi Frekuensi Nilai Hasil

Teks Menulis Teks Prosedur

\begin{tabular}{|c|c|c|c|}
\hline No & Nilai & $\begin{array}{c}\text { Frekue } \\
\text { nsi }\end{array}$ & $\begin{array}{c}\text { Presenta } \\
\text { se }(\%)\end{array}$ \\
\hline 1 & $\begin{array}{c}93,7 \\
5\end{array}$ & 2 & $8 \%$ \\
\hline 2 & 87,5 & 1 & $4 \%$ \\
\hline 3 & $\begin{array}{c}81,2 \\
5\end{array}$ & 8 & $32 \%$ \\
\hline 4 & 75 & 3 & $12 \%$ \\
\hline 5 & $\begin{array}{c}68,7 \\
5\end{array}$ & 3 & $12 \%$ \\
\hline 6 & 62,5 & 6 & $24 \%$ \\
\hline 7 & $\begin{array}{c}56,2 \\
5\end{array}$ & 2 & $8 \%$ \\
\hline
\end{tabular}

Berdasarkan tabel dapat digambarkan bahwa dari 25 orang yang dijadikan subjek penelitian pembelajaran

\begin{tabular}{|l|l|l|l|}
\hline 24 & Yuli Yanti & 13 & 13 \\
\hline 25 & Yuseran Pauji & 10 & 10 \\
\hline
\end{tabular}

Data dalam tabel merupakan variasi perolehan skor yang menunjukkan tingkat kemampuan menulis peserta didik.

\begin{tabular}{|c|c|c|}
\hline $\begin{array}{c}\text { Juml } \\
\text { ah }\end{array}$ & 25 & $100 \%$ \\
\hline
\end{tabular}

Tabel di atas menunjukkan bahwa dari 25 orang yang telah melakukan tes tidak seorangpun yang mendapat nilai 100 . Nilai tertinggi yang diperoleh 93,75 yang diperoleh 2 orang (8\%), sedangkan nilai terendah juga diperoleh 2 orang (8\%). Dari analisis diatas maka rata-rata menulis dapat dilihat pada tabel dibawah ini.

Tabel 3. Rata-rata Kemampuan Menulis Teks Prosedur

\begin{tabular}{|c|c|c|c|}
\hline No & $\begin{array}{c}\text { Nilai } \\
(\mathrm{X})\end{array}$ & $\begin{array}{c}\text { Frekuensi } \\
(\mathrm{f})\end{array}$ & (f) $\mathrm{X}$ \\
\hline 1 & 93,75 & 2 & 187,5 \\
\hline 2 & 87,5 & 1 & 87,5 \\
\hline 3 & 81,25 & 8 & 650 \\
\hline 4 & 75 & 3 & 225 \\
\hline 5 & 68,75 & 3 & 206,25 \\
\hline 6 & 62,5 & 6 & 375 \\
\hline 7 & 56,25 & 2 & 112,5 \\
\hline & & $\mathrm{N}=25$ & $\sum X=$ \\
& & & $1.843,75$ \\
\hline \multicolumn{2}{r|}{ Rata-rata } & $\frac{1.843,75}{25}$ & 73,75 \\
& & & \\
\hline
\end{tabular}

menulis teks prosedur kelas VII memperoleh nilai rata-rata 73,75 dengan kategori cukup mampu. 
Tabel 4. Klasifikasi Rata-Rata Menulis Teks Prosedur Dalam Beberapa Aspek

\begin{tabular}{|c|c|c|c|}
\hline No & Aspek & $\begin{array}{c}\text { Nilai } \\
\text { Rata- } \\
\text { rata }\end{array}$ & $\begin{array}{c}\text { Kategori } \\
\text { Kemampu } \\
\text { an }\end{array}$ \\
\hline 1 & Isi & 96 & $\begin{array}{c}\text { sangat } \\
\text { mampu }\end{array}$ \\
\hline 2 & Striktur & 83 & Mampu \\
\hline 3 & $\begin{array}{c}\text { kaidah } \\
\text { penulis } \\
\text { an }\end{array}$ & 34 & Kurang \\
\hline 4 & $\begin{array}{c}\text { Ciri } \\
\text { kebahas } \\
\text { aan }\end{array}$ & 78 & Cukup \\
\hline
\end{tabular}

Dari segi isi rata-rata menulis peserta didik dalam kategori sangat baik judul dan pemilihan topik sudah sesuai

\section{Pembahasan}

Dari hasil tes yang telah diberikan kepada 25 orang, peneliti melihat tidak ada yang belum mengetahui dengan jelas mengenai teks prosedur. Dalam menyusun teks prosedur ditemukan masih banyak peserta didik yang kekurangan dari segi struktur teks prosedur, namun hampir seluruh peserta didik menggunakan keempat struktur teks yakni isi, struktur, kaidah penulisan dan ciri kebahasaan. beberapa kesalahan peserta didik yang peneliti dapatkan seperti:

1. Dari segi penulisan judul tidak menggunakan huruf kapital di bagian awal, ada beberapa yang menuliskan judul dengan huruf kecil.

2. Dari segi isi peserta didik menggabungkan penulisan dengan huruf dengan isi. Dalam aspek struktur peserta didik sudah mampu memenuhi ketercapaian indikator, rata-rata sudah bisa menulis isi dengan menggunakan langkah atau urutan yang sesuai dengan struktur teks prosedur. Dari segi kaidah penulisan masih sangat kurang peserta didik masih belum bisa memperhatikan tata penulisan, Sedangkan dari segi kebahasaan sudah cukup baik ratarata peserta didik sudah dapat memperhatikan penomoran yang menunjukan urutan serta menggunkan kalimat perintah .

kapital dan kecil untuk membuat kata atau kalimat.

3. Kata ulang ditulis dengan angka 2.

4. Dalam tulisan peserta didik masih banyak yang tidak menggunakan tanda titik, dan koma seabagai pengganti kata penghubung dalam memisahkan bagian-bagian kalimat yang sejenis dan setara.

Data dari hasil tes yang telah diberikan dihitung untuk mendapatkan perolehan nilai yang dijadikan acuan untuk mengetahui kemampuan menulis teks prosedur. Dari hasil olah data secara keseluruhan ditemukan bahwa peserta didik yang mampu dalam menulis teks prosedur berjumlah 14 orang (56\%) dan yang tidak mampu dalam menulis teks prosedur berjumlah 11 orang (44\%). Secara keseluhan peserta didik kelas VII SMP 
Muhammadiyah 1 Banjarmasin secara individual сиkup mampu dengan memeroleh nilai rata-rata kemampuan menulis teks prosedur 73,75 . Namun secara

\section{Simpulan dan Saran}

\section{Simpulan}

Dalam proses pembelajaran guru tidak sepenuhnya berpedoman terhadap RPP. Dari yang peneliti amati ada beberapa hal yang ada didalam RPP tidak terlaksanakan seperti kegiatan mengomunikasikan dan kurangnya alat atau media yang digunakan saat proses belajar mengajar berlangsung.

Hasil penelitian menunjukkan peserta didik memperoleh nilai rata-rata $73,75(56 \%)$ dalam menulis teks prosedur. Nilai rata-rata aspek isi peserta didik 96 dalam kategori sangat mampu. Pada aspek struktur, nilai rata-rata peserta didik 83 dalam kategori mampu. Pada aspek kaidah penulisan nilai rata-rata 34 kategori kurang mampu, dan pada aspek ciri kebahasaan, nilai rata-rata 78 termasuk сикир татри. Hasil penilaian secara klasikal memeroleh nilai (56\%) maka kemampuan menulis peserta didik kelas VII SMP

\section{Daftar Pustaka}

Agustin Flaviyana, 2015 Pengertian, Tujuan, Ciri-ciri, dan Struktur Teks Prosedur Kompleks. Publikasi Daring. Diakses pada tanggal 23 Januari 2019 dari http://agustinflaviyanablogspot.com/ 2015/09/teks-prosedurkompleks.html?m=1 klasikal kelas VII SMP Muhammadiyah tidak tuntas secara klasikal karena peserta didik yang memperoleh nilai lebih dari 70 kurang dari (70\%).

Muhammadiyah 1 Banjarmasin tidak tuntas secara penilaian klasikal.

\section{Saran}

Berdasarkan hasil kesimpulan yang diperoleh dari penelitian, terdapat beberapa hal yang dapat dijadikan saran.

1. Bagi guru, diharapkan dapat memerhatikan kemampuan menulis dan memotivasi peserta didik mengenai minat menulis. Meskipun kemampuan menulis peserta didik secara individual dapat dikategorikan cukup maтри, namun dari segi penilaian klasikal kelas VII SMP Muhammadiyah tidak tuntas. Hendaknya guru masih perlu terus mengasah kemapuan dengan memberikan latihan praktik menulis kepada peserta didik.

2. Bagi peserta didik, untuk lebih rajin dan aktif selama proses pembelajaran untuk meningkatkan dan mengembangkan kemampuan menulis guna menunjang proses pembelajaran di sekolah.

Alvianti Aprilia, 2017. Peningkatan Kemampuan Menulis Teks Prosedur Kompleks dengan Media Audio Visual pada Siswa Kelas X SMK Negeri 1 Kabumen Tahun Pelajaran 2016/2017. 
Aqib, dkk. 2010 Metedologi Penilitan

Bandung: Alfabeta.

Ardiansyah, 2014. Teknik Picture and Picture dalam Pembelajaran Menulis Teks Prosedur Kelas VIII SMP Negeri 2 Takalar.

Dalman, H. 2016. Keterampilan Menulis. PT Raja Grafindo Persada Depok

Iskandarwassid dan Dadang Sunendar, Strategi Pembelajaran Bahasa, (Bandung: PT Remaja Rosadakarya, 2011)

Jauharoti Arifin, Keterampilan Dasar Berbahasa, (Surabaya: Pustaka Intelektual, 2009)

Yarmi Gusti. "Meningkatkan Kemampuan Menulis Kreatif Siswa Melalui Pendekatan Whole Language denga Teknik Menulis Jurnal”. Dalam
AR-RIAYAH "Pembelajaran Bahasa Indonesia dan Sastra (BASASTRA) di $S D$ dan MI'.Jurnal Pendidikan Dasar Vol. 2, no 1, 2018 STAIN Curup Bengkulu. Publikasi Daring. Diakses pada tanggal 24 Desember 2018.

Dalman, H. 2015. Penulisan Populer. PT Raja Grafindo Persada Depok.

Kemendikbud. 2013. Bahasa Indonesia Ekspresi Diri dan Alademik. Jakarta: Kementiran dan Kebudayaan.

Kementrian Pendidikan dan Kebudayaan, 2017. Buku Guru Bahasa Indonesia. Edisi Revisi Jakarta : Kementerian Pendidikan dan kebudayaan,2017.

Jurnal Perpektif Ilmu Pendidikan Vol 28 No 13 April 2014. Publikasi Daring. Diakses pada tanggal 24 Desember 2018 